\title{
POTENTIAL USE OF SPENT MUSHROOM SUBSTRATE OF LENTINULA EDODES AS A BIOFERTILIZER
}

\author{
Andrew Ravlikovsky ${ }^{1^{*}}$, Lyudmyla Symochko $^{2}$ \\ ${ }^{1 *}$ Uzhhord National University, Uzhhorod, Ukraine; Nature Green Ukraine LLC, Transcarpathian region, Ukraine; \\ ${ }^{2}$ Uzhhord National University, Uzhhorod, Ukraine; Institute of Agroecology and Environmental Management, Kyiv, \\ Ukraine;
}

*Corresponding author Andrew Ravlikovsky, e-mail: andrew@naturegreen.eu; lyudmilassem@gmail.com;

Received May 2020; Accepted June 2020; Published August 2020;

DOI: https://doi.org/10.31407/ijees10.314

\begin{abstract}
Spent mushroom substrate (SMS) is a by-product of mushroom growing. It is often classified as waste despite that it is high in organic matter and mineral micronutrient. In last 10 years, mostly in Europe and Asia, studies of potential ways of reuse of SMS were done. Most of them showed that spent mushroom substrate can be reused as a bioadditive or fertilizer. For Ukraine, where mushroom growing is on its rise, we've decided to test SMS from local producer as a fertilizer. Blueberry was selected as a test culture for this multiyear experiment. For the first year the following parameters were taken for studying: chemical composition of fertilized soil, number of soil microorganisms and the content of total microbial biomass, direction of soil microbiological processes. Spent mushroom substrate of Lentinula edodes (shiitake mushroom) was used as an experimental sample. Peat was used as a comparative sample. As a result of studying of the actual content of elements, in terms of $1 \mathrm{mg} / 100 \mathrm{~g}$ of dry matter for peat, the following data were obtained: $\mathrm{Ca}^{2+}-427.6$, $\mathrm{Mg}^{2+}-210.6, \mathrm{P}_{2} \mathrm{O}_{5}-78, \mathrm{~K}_{2} \mathrm{O}-29.09, \mathrm{~N}$ ammonium - 4.0, N nitrate - 1.61. For the SMS, they were as follows: $\mathrm{Ca}^{2+}$ 455.6, $\mathrm{Mg}^{2+}-729.0, \mathrm{P}_{2} \mathrm{O}_{5}-338, \mathrm{~K}_{2} \mathrm{O}-340.5, \mathrm{~N}$ ammonium - 41.0, $\mathrm{N}$ nitrate - 183.0. As a result of analysis of the cationic-anionic composition of the water extract, in terms of $1 \mathrm{mg}$-eq. / $100 \mathrm{~g}$, the following data were obtained for peat: $\mathrm{HCO}_{3}{ }^{-}-0.15, \mathrm{Cl}^{-}-0.30, \mathrm{Ca}^{2+}-0.29, \mathrm{Mg}^{2+}-0.50, \mathrm{Na}^{+}-0.21, \mathrm{~K}^{+}-0.10, \mathrm{SO}_{4}{ }^{2-}-1.34$. For the SMS, they were as follows: $\mathrm{HCO}_{3}{ }^{-}-0.01, \mathrm{Cl}^{-}-0.12, \mathrm{Ca}^{2+}-2.79, \mathrm{Mg}^{2+}-2.64, \mathrm{Na}^{+}-1.18, \mathrm{~K}^{+}-4.22, \mathrm{SO}_{4}{ }^{2-}-1.31$. The total salt content for peat was $0.11 \%, \mathrm{pH}-4.31$. For the SMS the total salt content was $0.37 \%, \mathrm{pH}-4.04$. For both soil samples the number of microorganisms and the content of total microbial biomass were determined. The enrichment of soil by SMS led to the growth of microbial biomass $(406.34 \pm 38.10)$. In the soil fertilized by SMS decreased number of oligotrophs more than in 3 times and pedotrophic microorganisms in 2 times in compare with soil fertilized by peat. Basing on the number of soil microorganisms coefficients of mineralization, oligotrophity, pedotrophity and transformation of organic matter were calculated. For soil fertilized by peat values of the coefficients were next: mineralization -1.0 , oligotrophity -1.56 , pedotrophity -1.78 , transformation of organic matter -94.61 . For soil fertilized by SMS we got next values: coefficient of mineralization -1.95 , coefficient of oligotrophity -1.21 , coefficient of pedotrophity -2.49 and coefficient of transformation of organic matter -26.31 .
\end{abstract}

Keywords: spent mushroom substrate, fertilizer, mineral micronutrients, number of microorganisms and the content of total microbial biomass, coefficients of mineralization, oligotrophity, pedotrophity and transformation of organic matter. 